\title{
Front Matter: Volume 7827
}

, "Front Matter: Volume 7827," Proc. SPIE 7827, Remote Sensing of Clouds and the Atmosphere XV, 782701 (8 November 2010); doi: 10.1117/12.882450

SPIE. Event: SPIE Remote Sensing, 2010, Toulouse, France 


\section{PROCEEDINGS OF SPIE}

\section{Remote Sensing of Clouds and the Atmosphere XV}

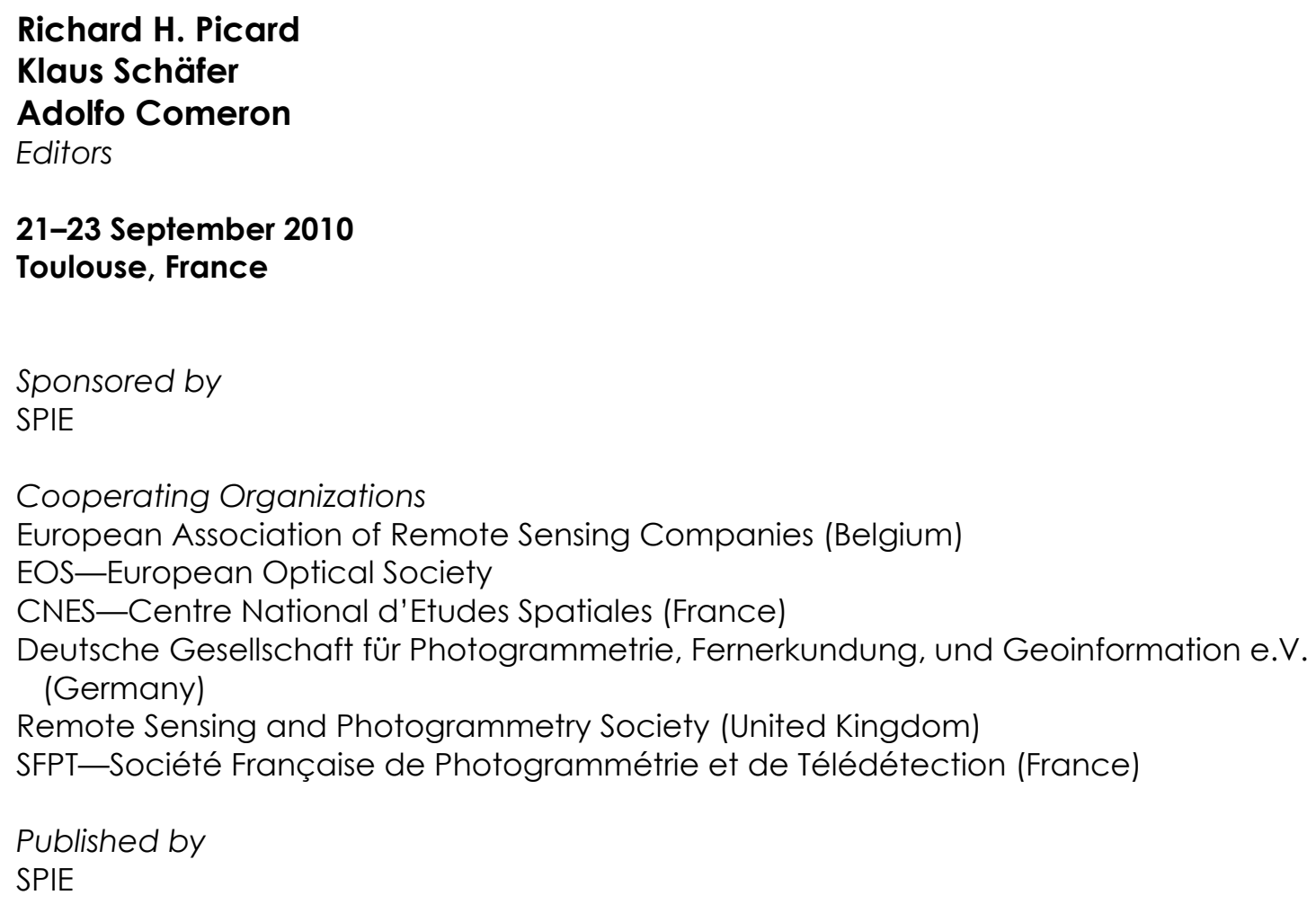

Volume 7827 
The papers included in this volume were part of the technical conference cited on the cover and title page. Papers were selected and subject to review by the editors and conference program committee. Some conference presentations may not be available for publication. The papers published in these proceedings reflect the work and thoughts of the authors and are published herein as submitted. The publisher is not responsible for the validity of the information or for any outcomes resulting from reliance thereon.

Please use the following format to cite material from this book:

Author(s), "Title of Paper," in Remote Sensing of Clouds and the Atmosphere XV, edited by

Richard H. Picard, Klaus Schäfer, Adolfo Comeron, Proceedings of SPIE Vol. 7827 (SPIE, Bellingham, WA, 2010) Article CID Number.

ISSN 0277-786X

ISBN 9780819483447

Published by

SPIE

P.O. Box 10, Bellingham, Washington 98227-0010 USA

Telephone +1 3606763290 (Pacific Time) · Fax +1 3606471445

SPIE.org

Copyright (@ 2010, Society of Photo-Optical Instrumentation Engineers

Copying of material in this book for internal or personal use, or for the internal or personal use of specific clients, beyond the fair use provisions granted by the U.S. Copyright Law is authorized by SPIE subject to payment of copying fees. The Transactional Reporting Service base fee for this volume is $\$ 18.00$ per article (or portion thereof), which should be paid directly to the Copyright Clearance Center (CCC), 222 Rosewood Drive, Danvers, MA 01923. Payment may also be made electronically through CCC Online at copyright.com. Other copying for republication, resale, advertising or promotion, or any form of systematic or multiple reproduction of any material in this book is prohibited except with permission in writing from the publisher. The CCC fee code is 0277-786X/10/\$18.00.

Printed in the United States of America.

Publication of record for individual papers is online in the SPIE Digital Library.

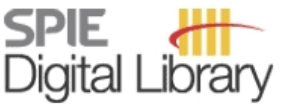

SPIEDigitalLibrary.org

Paper Numbering: Proceedings of SPIE follow an e-First publication model, with papers published first online and then in print and on CD-ROM. Papers are published as they are submitted and meet publication criteria. A unique, consistent, permanent citation identifier (CID) number is assigned to each article at the time of the first publication. Utilization of CIDs allows articles to be fully citable as soon they are published online, and connects the same identifier to all online, print, and electronic versions of the publication. SPIE uses a six-digit CID article numbering system in which:

- The first four digits correspond to the SPIE volume number.

- The last two digits indicate publication order within the volume using a Base 36 numbering system employing both numerals and letters. These two-number sets start with 00, 01, 02, 03, 04 , 05, 06, 07, 08, 09, OA, OB ... 0Z, followed by 10-1Z, 20-2Z, etc.

The CID number appears on each page of the manuscript. The complete citation is used on the first page, and an abbreviated version on subsequent pages. Numbers in the index correspond to the last two digits of the six-digit CID number. 


\section{Contents}

ix Conference Committee

xi Introduction

LIDAR MEASUREMENTS DURING RECENT 2010 EYJAFJALLAJÖKULL VOLCANIC ERUPTION: JOINT SESSION WITH CONFERENCE 7832

xiii EARLINET observations of the Eyjafjallajökull ash plume over Europe (Invited Paper) [7832 0J] G. Pappalardo, A. Amodeo, Istituto di Metodologie per I'Analisi Ambientale, CNR (Italy); A. Ansmann, Leibniz Institut für Troposphärenforschung (Germany); A. Apituley, Rijksinstituut voor Volksgezondheid en Milieu (Netherlands); L. Alados Arboledas, Univ. de Granada (Spain); D. Balis, Aristotle Univ. of Thessaloniki (Greece); C. Böckmann, Univ. Potsdam (Germany); A. Chaikovsky, Institute of Physics (Belarus); A. Comeron, Univ. Politècnica de Catalunya (Spain); G. D'Amico, Istituto di Metodologie per l'Analisi Ambientale, CNR (Italy); F. De Tomasi, Univ. del Salento (Italy); V. Freudenthaler, Ludwig-Maximilians-Univ. München (Germany); E. Giannakaki, Aristotle Univ. of Thessaloniki (Greece); A. Giunta, Istituto di Metodologie per l'Analisi Ambientale, CNR (Italy); I. Grigorov, Institute of Electronics (Bulgaria); O. Gustafsson, Swedish Defence Research Agency (Sweden); S. Gross, Ludwig-Maximilians-Univ. München (Germany); M. Haeffelin, Univ. Pierre et Marie Curie (France); M. Iarlori, Univ. degli Studi dell'Aquila (Italy); S. Kinne, H. Linné, Max-Planck-Institut für Meteorologie (Germany); F. Madonna, Istituto di Metodologie per l'Analisi Ambientale, CNR (Italy); R. Mamouri, National Technical Univ. of Athens (Greece); I. Mattis, Leibniz Institut für Troposphärenforschung (Germany); M. McAuliffe, Univ. College Cork (Ireland); F. Molero, Ctr. de Investigaciones Energéticas, Medioambientales y Tecnológicas (Spain); L. Mona, Istituto di Metodologie per l'Analisi Ambientale, CNR (Italy); D. Müller, Leibniz Institut für Troposphärenforschung (Germany); V. Mitev, Ctr. Suisse d'Electronique et de Microtechnique SA (Switzerland); D. Nicolae, National Institute of Research and Development for Optoelectronics (Romania); A. Papayannis, National Technical Univ. of Athens (Greece); M. R. Perrone, Univ. del Salento (Italy); A. Pietruczuk, Institute of Geophysics (Poland); M. Pujadas, Ctr. de Investigaciones Energéticas, Medioambientales y Tecnológicas (Spain); J.-P. Putaud, European Commission Joint Research Ctr. (Italy); F. Ravetta, Univ. Pierre et Marie Curie (France); V. Rizi, Univ. degli Studi dell'Aquila (Italy); I. Serikov, Max-Planck-Institut für Meteorologie (Germany); M. Sicard, Univ. Politècnica de Catalunya (Spain); V. Simeonov, Ecole Polytechnique Fédérale de Lausanne (Switzerland); N. Spinelli, Consorzio Nazionale Interuniversitario per le Scienze Fisiche della Materia (Italy); K. Stebel, Norwegian Institute for Air Research (Norway); T. Trickl, Karlsruher Institut für Technologie (Germany); U. Wandinger, Leibniz Institut für Troposphärenforschung (Germany); X. Wang, Consorzio Nazionale Interuniversitario per le Scienze Fisiche della Materia (Italy); F. Wagner, Univ. de Évora (Portugal); M. Wiegner, Ludwig-Maximilians-Univ. München (Germany)

xxii Lidar observations of the Eyjafjallajökull volcanic ash plume at Leipzig, Germany [7832 0L] M. Tesche, A. Ansmann, A. Hiebsch, I. Mattis, J. Schmidt, P. Seifert, U. Wandinger, Leibniz Institut für Troposphärenforschung (Germany) 
xxxi Characterization of the Eyjafjallajökull ash-plume by means of lidar measurements over the Munich EARLINET-site [7832 0M]

S. Groß, J. Gasteiger, V. Freudenthaler, F. Schnell, M. Wiegner, Ludwig-Maximilians-Univ. München (Germany)

xxxix Mix of volcanic ash and Saharan dust over Romania during Eyjafjallajökull eruption [7832 ON]

D. Nicolae, A. Nemuc, L. Belegante, National Institute of Research and Development for Optoelectronics (Romania)

xIviii EARLINET observations of the Eyjafjallajökull ash plume over Greece [7832 00]

D. Balis, E. Giannakaki, Aristotle Univ. of Thessaloniki (Greece); R. E. Mamouri, P. Kokkalis,

A. Papayannis, G. Tsaknakis, National Technical Univ. of Athens (Greece)

Ivi Airborne measurements of the Eyjafjallajökull volcanic ash plume over northwestern Germany with a light aircraft and an optical particle counter: first results [7832 OP] K. Weber, A. Vogel, C. Fischer, G. van Haren, T. Pohl, Univ. of Applied Sciences Düsseldorf (Germany)

Ixxi Characterization of Iceland volcanic aerosols by UV-polarization lidar at Lyon, southwestern Europe [7832 0Q]

A. Miffre, G. David, B. Thomas, P. Rairoux, Lab. de Spectrométrie Ionique et Moléculaire, CNRS, Univ. Claude Bernard Lyon 1 (France)

Ixxx Temporal and spatial structure of a volcanic ash cloud: ground-based remote sensing and numerical modeling [7832 OR]

K. Schäfer, Karlsruher Institut für Technologie (Germany); W. Birmili, Leibniz Institu† für Troposphärenforschung (Germany); J. Cyrys, Helmholtz Zentrum München GmbH (Germany); S. Emeis, R. Forkel, Karlsruher Institut für Technologie (Germany); S. Gilge, Deutscher Wetterdienst (Germany); C. Münkel, Vaisala GmbH (Germany); M. Pitz, Helmholtz Zentrum München GmbH (Germany); L. Ries, Umweltbundesamt (Germany); P. Suppan,

Karlsruher Institut für Technologie (Germany)

\section{SESSION 1 REMOTE SENSING OF CLOUDS}

782702 Estimating scaled cloud optical thickness from SEVIRI by implementing a semi-analytical cloud retrieval algorithm [7827-02]

P. Pandey, Flemish Institute for Technological Research (Belgium) and Catholic Univ. Leuven (Belgium); K. De Ridder, Flemish Institute for Technological Research (Belgium); N. Van Lipzig, Catholic Univ. Leuven (Belgium)

782703 The use of EUMETSAT cloud mask product for astronomical site testing [7827-03]

M. S. Sarazin, European Organisation for Astronomical Research in the Southern Hemisphere (Germany); C. Dougnac V., Univ. de Valparaiso (Chile)

\section{SESSION 2 LIDAR, RADAR, AND PASSIVE ATMOSPHERIC MEASUREMENT TECHNIQUES}

782704 Atmospheric boundary-layer height estimation by adaptive Kalman filtering of lidar data [7827-05]

S. Tomás, F. Rocadenbosch, M. Sicard, Univ. Politècnica de Catalunya (Spain) 
782705 Supercooled large drop detection with NASA's Icing Remote Sensing System [7827-06] D. J. Serke, National Ctr. for Atmospheric Research (United States); A. L. Reehorst, NASA Glenn Research Ctr. (United States); M. K. Politovich, National Ctr. for Atmospheric Research (United States)

782706 Application of continuous remote sensing of mixing layer height for assessment of airport air quality [7827-07]

K. Schäfer, Karlsruher Institut für Technologie (Germany); C. Helmis, National and Kapodistrian Univ. of Athens (Greece); S. Emeis, Karlsruher Institut für Technologie (Germany); G. Sgouros, National and Kapodistrian Univ. of Athens (Greece); R. Kurtenbach, P. Wiesen, Bergische Univ. Wuppertal (Germany); C. Münkel, Vaisala GmbH (Germany); C. Jahn, M. Hoffmann, Karlsruher Institut für Technologie (Germany); E. Anamaterou, M. O'Connor, Athens International Airport S.A. (Greece)

782707 Comparison of different remote sensing methods for mixing layer height monitoring [7827-08]

S. Emeis, K. Schäfer, Karlsruher Institut für Technologie (Germany); C. Münkel, Vaisala GmbH (Germany); R. Friedl, P. Suppan, Karlsruher Institut für Technologie (Germany)

\section{SESSION 3 ATMOSPHERIC PROFILING OF AEROSOLS, TRACE GASES, AND METEOROLOGICAL} PARAMETERS I

$7827 \mathrm{OA}$ The quest for an OCO (Orbiting Carbon Observatory) re-flight [7827-10] R. R. Basilio, T. R. Livermore, Y. J. Shen, H. R. Pollock, Jet Propulsion Lab. (United States)

7827 OB The Atmospheric Infrared Sounder (AIRS) on the NASA Aqua Spacecraft: a general remote sensing tool for understanding atmospheric structure, dynamics, and composition [7827-11] T. S. Pagano, M. T. Chahine, E. J. Fetzer, Jet Propulsion Lab. (United States)

\section{SESSION 4 ATMOSPHERIC PROFILING OF AEROSOLS, TRACE GASES, AND METEOROLOGICA} PARAMETERS II

7827 OD Spectro-radiometric measurements of non-variant targets intended for the removal of atmospheric effects from satellite images: the case study of Lemesos area in Cyprus [7827-14]

D. G. Hadjimitsis, K. Themistocleous, V. Trigkas, A. Matsas, Cyprus Univ. of Technology (Cyprus); R. Adrianos, National Observatory of Athens (Greece); C. Nektarios, Foundation for Research and Technology - Hellas (Greece)

7827 OE Accuracy assessment of atmospheric correction algorithms using sun-photometers (AERONET), lidar system, and in situ spectroradiometers [7827-15]

K. Themistocleous, D. G. Hadjimitsis, Cyprus Univ. of Technology (Cyprus); A. Retalis, National Observatory of Athens (Greece); N. Chrysoulakis, Foundation for Research and Technology - Hellas (Greece)

7827 OF New method of deducing the refractive index of individual aerosol particles [7827-17] X.-B. Li, W.-Y. Zhu, Q.-S. XU, H.-L. Wei, H.-L. Hu, Anhui Institute of Optics and Fine Mechanics (China) 
SESSION 5 ATMOSPHERIC PROFILING OF AEROSOLS, TRACE GASES, AND METEOROLOGICAL PARAMETERS III

7827 OG CHRISTINE: code for high resolution satellite mapping of optical thickness and of Ångstrom exponent [7827-20]

N. I. Sifakis, National Observatory of Athens (Greece); C. Iossifidis, National Technical Univ. of Athens (Greece); C. Kontoes, National Observatory of Athens (Greece)

$7827 \mathrm{OH}$ Study of AERONET data of nearby stations in the Canary Islands: application to infer astronomical extinction coefficient at elevated altitudes [7827-21]

A. Bounhir, Z. Benkhaldoun, Univ. Cadi Ayyad (Morocco)

SESSION 6

REMOTE SENSING BY FTIR, DOAS, AND OTHER SPECTROMETRIC METHODS

7827 Ol Long-term air quality study by DOAS within Beijing [7827-22]

K. Schäfer, Karlsruher Institut für Technologie (Germany); Y. Wang, J. Xin, H. Ling, Institute of Atmospheric Physics (China); P. Suppan, Karlsruher Institut für Technologie (Germany)

7827 0J An infrared hyperspectral sensor for remote sensing of gases in the atmosphere [7827-49] S. Sabbah, P. Rusch, J.-H. Gerhard, Sigma ElectroOptics GmbH (Germany); R. Harig, Technische Univ. Hamburg-Harburg (Germany)

REMOTE SENSING OF THE MIDDLE AND UPPER ATMOSPHERE

$7827 \mathrm{OL}$ Effects of water vapor fluctuations on atmospheric limb radiance structure [7827-25]

C. Quang, V. Rialland, A. Roblin, ONERA (France)

$7827 \mathrm{OM} \quad$ Low-latitude thermal semidiurnal tide: longitudinal and seasonal variations based on ground-based measurements from Arecibo and Maui, space-based measurements by SABER, and modeling with GSWM-02 [7827-26]

J. S. Friedman, Arecibo Observatory (United States); X. Zhang, X. Chu, J. M. Forbes, Univ. of Colorado at Boulder (United States)

\section{SESSION 7 RADIATIVE TRANSFER I}

$782700 \quad$ Putting Terra CERES instruments on the same radiometric scale [7827-28]

Z. P. Szewczyk, Science Systems and Applications, Inc. (United States); K. J. Priestley, NASA Langley Research Ctr. (United States); D. R. Walikainen, Science Systems and Applications, Inc. (USA); N. G. Loeb, NASA Langley Research Ctr. (United States); G. L. Smith, National Institute of Aerospace (United States)

7827 OP The OMPS Limb Profiler instrument: two-dimensional retrieval algorithm [7827-29]

D. F. Rault, NASA Langley Research Ctr. (United States); R. Spurr, RT solutions (United States) 
$7827 \mathrm{OQ}$ Retrieval of intensive aerosol properties from MFRSR observations: partly cloudy cases [7827-30]

E. Kassianov, J. Barnard, L. K. Berg, C. Flynn, C. Long, Pacific Northwest National Lab. (United States)

7827 OR The effect of turbulent temperature fluctuations on vapor detection by ground-based passive infrared sensors at near horizon line of sight [7827-31]

A. Ben-David, U.S. Army Edgewood Chemical Biological Ctr. (United States); A. Ifarraguerri, Science Applications International Corp. (United States)

7827 OS Recent advances in the simulation of partly cloudy scenes [7827-48]

S. Richtsmeier, R. Sundberg, Spectral Sciences, Inc. (United States)

7827 OT Monte Carlo modeling in the problem of lidar remote sensing of clouds from satellites [7827-33]

B. A. Kargin, Institute of Computational Mathematics and Mathematical Geophysics (Russian Federation) and Novosibirsk State Univ. (Russian Federation); A. B. Kargin, Institute of Computational Mathematics and Mathematical Geophysics (Russian Federation);

M. V. Lavrov, Novosibirsk State Univ. (Russian Federation)

POSTER SESSION: ATMOSPHERIC PROFILING OF AEROSOLS, TRACE GASES, AND METEOROLOGICAL PARAMETERS

7827 OW A method analyzing aerosol particle shape and scattering based on imaging [7827-36] S. Shao, Y. Yao, R. Rao, Anhui Institute of Optics and Fine Mechanics (China)

7827 OX Detection of hazardous storms over South Africa using MSG/SEVIRI image data [7827-37] C. H. Hardy, A. L. Nel, Univ. of Johannesburg (South Africa)

7827 OY AERONET and Euroskyrad (ESR) aerosol optical depth intercomparison on Cimel CE318 and Prede POM01 radiometers [7827-38]

V. Estellés, Univ. de València (Spain); M. Campanelli, Consiglio Nazionale delle Ricerche (Italy); T. J. Smyth, Plymouth Marine Lab. (United Kingdom); M. P. Utrillas,

J. A. Martínez-Lozano, Univ. de València (Spain)

$7827 \mathrm{OZ}$ The infrared scatter characteristics of dust aerosol and cloud droplet particle [7827-39]

Z. Hao, F. Gong, D. Wang, J. Chen, State Oceanic Administration (China)

POSTER SESSION: REMOTE SENSING BY FTIR, DOAS, AND OTHER SPECTROMETRIC METHODS

782710 Development of a VDI guideline for passive FTIR measurements in the atmosphere [7827-40] K. Schäfer, Karlsruher Institut für Technologie (Germany); R. Harig, Technische Univ. Hamburg-Harburg (Germany); T. Blumenstock, Karlsruher Institut für Technologie (Germany); N. Höfert, Verein Deutscher Ingenieure (Germany); K. Weber, Fachhochschule Düsseldorf (Germany) 
782711 Temporal and spatial characteristics of atmospheric methane in the Yangtze River basin and the analysis of the main environmental impact factors [7827-41]

$\mathrm{H}$. Wan, Nanjing Institute of Geography and Limnology (China) and Nanjing Univ. (China);

Z. Qin, Nanjing Univ. (China); Y. Liu, Nanjing Institute of Geography and Limnology (China); Y. XU, X. Zhang, Nanjing Univ. (China)

POSTER SESSION: LIDAR, RADAR, AND PASSIVE ATMOSPHERIC MEASUREMENT TECHNIQUES

782712 Mapping temporal evolution of water vapour in troposphere by interferometric SAR data [7827-42]

P. Mateus, G. Nico, J. Catalão, Univ. of Lisbon (Portugal)

782713 Interpolating MERIS and GPS measurements of precipitable water vapour (PWV) to estimate atmospheric phase delay maps [7827-43]

P. Mateus, G. Nico, J. Catalão, Univ. of Lisbon (Portugal)

782714 Comparison of precipitable water vapor (PWV) maps derived by GPS, SAR interferometry, and numerical forecasting models [7827-44]

P. Mateus, G. Nico, R. Tomé, J. Catalão, P. Miranda, Univ. of Lisbon (Portugal)

POSTER SESSION: REMOTE SENSING OF CLOUDS

782718 A dual frequency millimetre wave radar for cloud characterization [7827-34]

H. Essen, S. Sieger, Fraunhofer FHR (Germany)

Author Index 


\title{
Conference Committee
}

\author{
Symposium Chair \\ Steven P. Neeck, NASA Headquarters (United States) \\ Symposium Cochair
}

Karin Stein, Fraunhofer-Institut für Optronik, Systemtechnik und Bildauswertung (Germany)

\section{Conference Chairs}

Richard H. Picard, Air Force Research Laboratory (United States)

Klaus Schäfer, Karlsruher Institut für Technologie (Germany)

Adolfo Comeron, Universitat Politècnica de Catalunya (Spain)

Michiel van Weele, Koninklijk Nederlands Meteorologisch Instituut

(Netherlands)

Programme Committee

Aldo Amodeo, Consiglio Nazionale delle Ricerche (Italy)

Evgueni I. Kassianov, Pacific Northwest National Laboratory (United States)

Christopher J. Mertens, NASA Langley Research Center (United States)

Nicolaos I. Sifakis, National Observatory of Athens (Greece)

Konradin Weber, Fachhochschule Düsseldorf (Germany)

Session Chairs

Lidar Measurements during Recent 2010 Eyjafjallajökull Volcanic Eruption: Joint Session with Conference 7832

Upendra N. Singh, NASA Langley Research Center (United States)

Adolfo Comeron, Universitat Politècnica de Catalunya (Spain)

Klaus Schäfer, Karlsruher Institut für Technologie (Germany)

1 Remote Sensing of Clouds

Evgueni I. Kassianov, Pacific Northwest National Laboratory (United States)

2 Lidar, Radar, and Passive Atmospheric Measurement Techniques

Adolfo Comeron, Universitat Politècnica de Catalunya (Spain) 
3 Atmospheric Profiling of Aerosols, Trace Gases, and Meteorological Parameters I

Adolfo Comeron, Universitat Politècnica de Catalunya (Spain)

$4 \quad$ Atmospheric Profiling of Aerosols, Trace Gases, and Meteorologica Parameters II

Klaus Schäfer, Karlsruher Institut für Technologie (Germany)

5 Atmospheric Profiling of Aerosols, Trace Gases, and Meteorological Parameters III

Klaus Schäfer, Karlsruher Institut für Technologie (Germany)

6 Remote Sensing by FTIR, DOAS, and Other Spectrometric Methods Klaus Schäfer, Karlsruher Institut für Technologie (Germany)

$7 \quad$ Remote Sensing of the Middle and Upper Atmosphere Christopher J. Mertens, NASA Langley Research Center (United States)

8 Radiative Transfer I

Christopher J. Mertens, NASA Langley Research Center (United States)

9 Radiative Transfer II

Richard H. Picard, Air Force Research Laboratory (United States) 


\section{Introduction}

The Fifteenth Conference on Remote Sensing of Clouds and the Atmosphere was held in Toulouse, France, as part of SPIE Europe Remote Sensing 2010. The conference included 43 papers divided into nine oral sessions, a poster session, and a special joint session. The areas covered in the regular sessions were cloud remote sensing; lidar, radar, and passive atmospheric measurement techniques; profiling of aerosols, trace gases, and meteorological parameters; spectrometric methods, including FTIR and DOAS; middle/upper-atmosphere remote sensing; and radiative transfer. The special session on atmospheric measurements during the 2010 eruption of the Eyjafjallajökull volcano in Iceland was a joint session with Conference 7832, Lidar Technologies, Techniques, and Measurements for Atmospheric Remote Sensing.

The papers presented included a broad range of methodologies from basic theoretical principles of atmospheric phenomena and remote-sensing techniques to end-user applications of remote-sensing products.

Remote sensing from space and ground, as well as critical enabling technologies and disciplines, were all addressed. Space-based remote sensing has been traditionally applied to producing global data products and investigating relatively large-scale phenomena, and current and planned satellite instruments are indeed continuing to yield useful knowledge in this area. However, there is increasing activity in applying satellite-based sensors to more local measurements, including monitoring of the sources and dispersal of air pollutants. Ground-based instruments, on the other hand, are inherently adapted to investigating small-scale and local phenomena. Nevertheless, by forming networks of ground-based instruments - and now even global-scale networks of such networks - coordinated data over extended regions and over the whole globe will be obtained. Thus the gaps between the small and large scale and between local and global phenomena are being bridged by the evolution of both ground-based and space-based sensors as well as improved methods of analysis. The coordination of measurements among ground-based sensor networks and between ground-based and space-based sensors depends on accurate cross-calibration methods. In addition, accompanied by powerful analysis and computational techniques, such coordinated measurements permit the cross-validation of the resulting data sets, yielding data sets of superior quality.

Progress in atmospheric remote sensing is also manifesting itself in a number of other ways. Accurate and efficient radiative transfer is an essential technique in nearly all atmospheric remote sensing, and radiative transfer methods are enabling the treatment of ever more complex geometries and boundary conditions. The remote sensing of clouds and remote sensing of the atmosphere and the earth surface in the presence of clouds are among the chief 
beneficiaries of such advances. Passive measurement techniques are developing increased spatial and spectral resolution, as well as enhanced specificity in detecting particular atmospheric gases and aerosols, thus providing more effective complements to active lidar/radar techniques. Atmospheric remote sensing at higher altitudes in the stratosphere and middle atmosphere and even the thermosphere/ionosphere - is also becoming more effective by incorporating perturbations due to gravity waves, tides, and geomagnetic storms.

In the future we expect to see continued evolution of space-based and groundbased sensor concepts and implementations, as well as improved methods of analysis and new applications. We also expect a continuation of current trends to smaller-scale measurements from space, to more extensive and even global webs of ground-based instruments, to retrievals depending on fewer and less idealised approximations, and to more pervasive sensing from a broader range of platforms, including unmanned aerial vehicles and micro/nano/pico-satellites.

These proceedings contain the reviewed and revised papers corresponding to the regular oral and poster conference presentations. Papers from the special joint session on the Iceland volcanic aerosols were given lidar-conference (7832) paper numbers, but are included in the proceedings of both of the sponsoring conferences.

We would like to thank the authors for the very high quality of their papers and thank the SPIE staff for their invaluable work in the organization of the conference and the editing of these proceedings. We also thank Aldo Amodeo, Evgueni Kassianov, Christopher J. Mertens, Nicolaos Sifakis, and Konradin Weber - all members of the conference Programme Committee - for assistance in reviewing these papers, including the papers from the joint session.

Richard H. Picard Klaus Schäfer Adolfo Comerón 